\title{
Identification and Quantification of Rhizoctonia solani and R. oryzae Using Real-Time Polymerase Chain Reaction
}

\author{
P. A. Okubara, K. L. Schroeder, and T. C. Paulitz
}

U.S. Department of Agriculture-Agricultural Research Service, Root Disease and Biological Control Research Unit, Pullman, Washington 99164-6430.

Accepted for publication 4 March 2008.

\section{ABSTRACT}

Okubara, P. A., Schroeder, K. L., and Paulitz, T. C. 2008. Identification and quantification of Rhizoctonia solani and $R$. oryzae using real-time polymerase chain reaction. Phytopathology 98:837-847.

Rhizoctonia solani and $R$. oryzae are the principal causal agents of Rhizoctonia root rot in dryland cereal production systems of the Pacific Northwest. To facilitate the identification and quantification of these pathogens in agricultural samples, we developed SYBR Green I-based real-time quantitative-polymerase chain reaction (Q-PCR) assays specific to internal transcribed spacers ITS1 and ITS2 of the nuclear ribosomal DNA of $R$. solani and $R$. oryzae. The assays were diagnostic for $R$. solani AG-2-1, AG-8, and AG-10, three genotypes of $R$. oryzae, and an AG-Ilike binucleate Rhizoctonia species. Quantification was reproducible at or below a cycle threshold $(\mathrm{Ct})$ of 33 , or 2 to $10 \mathrm{fg}$ of mycelial DNA from cultured fungi, 200 to $500 \mathrm{fg}$ of pathogen DNA from root extracts, and 20 to $50 \mathrm{fg}$ of pathogen DNA from soil extracts. However, pathogen DNA could be specifically detected in all types of extracts at about 100-fold below the quantification levels. Soils from Ritzville, WA, showing acute Rhizoctonia bare patch harbored 9.4 to 780 pg of $R$. solani AG-8 DNA per gram of soil.. Blastn, primer-template duplex stability, and phylogenetic analyses predicted that the Q-PCR assays will be diagnostic for isolates from Australia, Israel, Japan, and other countries.

Additional keywords: fungal pathogen, phylogeny, root disease, soilborne pathogen, wheat.
Rhizoctonia root rot of wheat and barley, caused by Rhizoctonia solani Kühn (teleomorph Thanatephorus cucumeris [Frank] Donk) and $R$. oryzae Ryker \& Gooch (teleomorph Waitea circinata Warcup \& Talbot), is one of several root diseases that occur in cereal production regions worldwide $(10,30)$ and accounts for 10 to $20 \%$ annual reduction in yield in the dryland (nonirrigated) regions of the Pacific Northwest (PNW) $(4,5,36,51)$. For $R$. solani, current classification of isolates that are pathogenic is largely based on grouping into anastomosis groups (AG), defined on the basis of hyphal fusion reactions. $R$. solani AG- 8 is the primary causal agent of root rot in direct-seeded (no-till) systems $(2,6$, 40,46). This pathogen persists on crop residue and causes stunting of plants in the field, often in patches culminating in yearly economic losses that are causing some PNW growers to abandon direct seeding. $R$. solani AG-2-1 is pathogenic to canola, mustard, and pea (36), crops that are used in rotation with wheat. $R$. solani AG-10, prevalent in the PNW, is associated with root rot $(24,31)$. Although its pathogenicity in the field is not well-documented, AG-10 isolates are less aggressive on wheat and barley than AG8 , but cause disease on broadleaf rotation crops in the greenhouse (unpublished data). Pre-emergence damping-off, yield-limiting to PNW cereals $(28,40)$, is primarily associated with severe infections of $R$. oryzae $(28,37,39)$ that result in necrosis of emerging roots and death of germinating seedlings (38). R. oryzae also

Corresponding author: P. A. Okubara; E-mail address: pokubara@wsu.edu

* The $e$-Xtra logo stands for "electronic extra" and indicates that the online version contains four additional tables showing $\mathrm{Ct}$ values for Rhizoctonia and nonRhizoctonia nontarget DNAs, GenBank accessions used for in silico analyses, and the effect of polyvinyl pyrrolidone on PCR.

\section{doi:10.1094/PHYTO-98-7-0837}

This article is in the public domain and not copyrightable. It may be freely reprinted with customary crediting of the source. The American Phytopathological Society, 2008. causes uneven stand height in the cereals (38) and is pathogenic to some legumes, including pea, chickpea, and lentil (6).

Rhizoctonia root diseases in the PNW continue to pose challenges to growers and pathologists; fungicide applications and rotation are costly or not completely effective $(8,38,42,46)$, and deployable genetic resistance is not available to breeders $(39,48)$. Improved management of Rhizoctonia in PNW cereal production systems will be aided by a method to rapidly determine the distribution and population densities of pathogenic species, and compare pathogen populations under different management regimens.

Current methods for quantification of Rhizoctonia spp. are labor intensive and therefore not suitable for large-scale pathogen sampling. These methods involve direct plating of soil pellets or particles on media, or removal of organic matter from soil fractions using sieves prior to plating (37). Dilution plate count enumerations are impractical because of low population densities of Rhizoctonia spp. in the soil. Baiting of Rhizoctonia from soil is useful for diagnosis (37) but not for quantification. Microscopybased diagnosis can be used to distinguish $R$. solani from $R$. oryzae (37), but additional procedures (18) are needed to identify AG. Molecular assays are practical alternatives to morphologybased identification and require less familiarity with morphological characteristics of Rhizoctonia spp.

The intra-specific diversity among the internal transcribed spacer (ITS) regions of the nuclear ribosomal DNA in Rhizoctonia render them suitable for molecular assays $(14,20,29,50)$ that take advantage of the correlation between ITS polymorphism and AG $(7,13,15,19,44)$. Hybridization-based approaches $(14,23)$ provide a more comprehensive pathogen profile than polymerase chain reaction (PCR)-based assays, but the latter generally are more sensitive and rapid. Conventional (endpoint) PCR assays specific to $R$. solani AG-1 and AG-2 $(27,44)$, AG-4 (3), and AG-G (21), and Rhizoctonia spp. of the rice sheath-blight complex (17), Rhizoctonia root rot complex of wheat (28), and banded leaf and 
sheath blight of maize (34) have advanced understanding of pathogen host range and occurrence in disease complexes. Realtime PCR confers the additional advantage of quantification for a wide range of pathogen DNA concentrations, and can distinguish at the species (22) and AG (20) levels.

Our objectives were to identify the $R$. solani and $R$. oryzae currently associated with Rhizoctonia root rot and damping off in PNW cereal production systems, and to develop rapid, sensitive, and quantitative assays that distinguish these Rhizoctonia at the $\mathrm{AG}$ or genotype level. We used real-time quantitative-polymerase chain reaction (Q-PCR) of the ITS regions to detect four AG of $R$. solani and three ITS genotypes of $R$. oryzae. Q-PCR provides simultaneous detection and quantification of a wide concentration range of target DNA compared to conventional (endpoint) PCR, and has been adapted for many soilborne pathogens $(22,32,45)$, including $R$. solani AG-3 (20). Here, we describe Q-PCR assays for $R$. solani AG-2-1, AG-8, and AG-10, an AG-I-like binucleate Rhizoctonia species, and three genotypes of $R$. oryzae that can be adapted for cultured fungi, soil samples, and roots.

\section{MATERIALS AND METHODS}

Isolates and cultures. Mycelia of Rhizoctonia and Rhizoctonia-like isolates (Table 1) were baited from agricultural soils displaying root rot or bare patch using toothpicks (37) or directly cultured from roots on water agar supplemented with chloramphenicol at 100 and $1 \mu \mathrm{g} / \mathrm{ml}$ a.i. benomyl (Benlate, DuPont, Wilmington, DE). Hyphal tips were isolated from mixed cultures prior to use in the study. All isolates were maintained on potato dextrose agar (PDA) slants (Difco, Sparks, NV) at $4^{\circ} \mathrm{C}$, and

TABLE 1. Rhizoctonia and Rhizoctonia-like isolates used in this study

\begin{tabular}{|c|c|c|c|c|c|c|}
\hline Isolate & Location $^{\mathrm{a}}$ & Host $^{\mathrm{b}}$ & Group $^{c}$ & GB accession & Identification method $^{\mathrm{d}}$ & Reference \\
\hline \multicolumn{7}{|c|}{$R$. solani and like reference isolates } \\
\hline $\mathrm{C}-1$ & Clyde, WA & SB & Rs AG-8 & & & 48 \\
\hline 1202325 & NF Garfield & $\mathrm{W}$ & Rs AG-2-1 & DQ356412 & & This study \\
\hline 1202334 & NF Garfield & W & AG-I-like & DQ356409 & & This study \\
\hline 070304 & Lind, WA & C-WW & Rs AG-8 & DQ356413 & Q-PCR & This study \\
\hline 100249 & Lind, WA & WW & AG-I-like & DQ356407 & & This study \\
\hline 120208 & PCFS Pullman & SW & Rs AG-2-1 & DQ356411 & & This study \\
\hline 120203 & PCFS Pullman & SW & Rs AG-10 & DQ356410 & & This study \\
\hline AG-2-1R & PNW & Rs AG-2-1 & & & & M. Mazzola \\
\hline AG-10R & PNW & Rs AG-10 & & & & M. Mazzola \\
\hline 100278 & Walla Walla, WA & $\mathrm{CP}$ & Rs AG-10 & DQ356408 & & This study \\
\hline \multicolumn{7}{|c|}{$R$. oryzae reference isolates } \\
\hline 120232 & CAF Pullman & SW & Ro group I & DQ356414 & & This study \\
\hline Ro4-4 & PNW & & Ro group II & DQ356415 & & This study \\
\hline 0801344 & Lewiston, ID & pea & Ro group III & DQ356416 & & 35 \\
\hline 0801387 & Mockonema, WA & $\mathrm{SB}$ & Ro group III & DQ356417 & & 35 \\
\hline \multicolumn{7}{|c|}{ Other $R$. solani and like } \\
\hline 1202262 & PF Garfield & SB & AG-8 & & ITS & This study \\
\hline 1202265 & NF Garfield & SW & AG-2-1 & & & This study \\
\hline 1202320 & NF Garfield & SW & AG-2-1 & & & This study \\
\hline 1202339 & NF Garfield & SW & AG-I-like & & Q-PCR & This study \\
\hline 1202342 & NF Garfield & $\mathrm{SB}$ & AG-2-1 & & Q-PCR & This study \\
\hline 1202351 & NF Garfield & SB & AG-I-like & & Q-PCR & This study \\
\hline 070302 & Lind, WA & C-WW & AG-2-1 & & Q-PCR & This study \\
\hline 070307 & Lind, WA & C-WW & AG-8 & & Q-PCR & This study \\
\hline 070308 & Lind, WA & C-WW & AG-8 & & Q-PCR & This study \\
\hline 070316 & Lind, WA & C-WW & none & & Q-PCR & This study \\
\hline 070325 & Lind, WA & C-WW & AG-2-1 & & Q-PCR & This study \\
\hline 070326 & Lind, WA & WW & AG-2-1 & & Q-PCR & This study \\
\hline 070362 & Lind, WA & Canola & AG-2-1 & & & This study \\
\hline 100250 & Lind, WA & WW & AG-I-like & & & This study \\
\hline 120266 & Mockonema, WA & SB & AG-10 & & Q-PCR & This study \\
\hline 120281 & Mockonema, WA & SB & AG-8 & & Q-PCR & This study \\
\hline 050520 & CAF Pullman & Lentil & AG-10 & & & This study \\
\hline 050521 & CAF Pullman & Lentil & AG-10 & & & This study \\
\hline 050534 & CAF Pullman & Lentil & AG-2-1 & & & This study \\
\hline 050538 & CAF Pullman & Lentil & AG-2-1 & & & This study \\
\hline 050540 & CAF Pullman & WW & AG-2-1 & & & This study \\
\hline 050533 & CAF Pullman & Lentil & AG-8 & & & This study \\
\hline 050539 & CAF Pullman & Lentil & AG-8 & & & This study \\
\hline 070582 & CAF Pullman & WW & AG-10 & & & This study \\
\hline 090410 & CAF Pullman & SW & AG-2-1 & & Q-PCR & This study \\
\hline 090415 & CAF Pullman & SW & AG-2-1 & & Q-PCR & This study \\
\hline 090427 & CAF Pullman & WW & AG-2-1 & & Q-PCR & This study \\
\hline 090431 & CAF Pullman & WW & AG-2-1 & & Q-PCR & This study \\
\hline 090434 & CAF Pullman & WW & AG-2-1 & & Q-PCR & This study \\
\hline 090435 & CAF Pullman & WW & AG-2-1 & & Q-PCR & This study \\
\hline 100516 & CAF Pullman & WW & AG-10 & & & This study \\
\hline 100525 & CAF Pullman & WW & AG-10 & & & This study \\
\hline
\end{tabular}

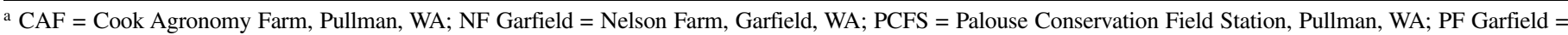
Pennell Farm, Garfield, WA.

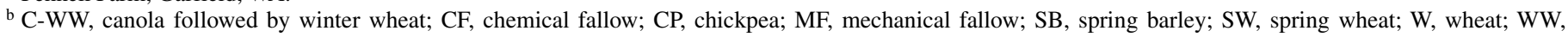
winter wheat.

c Anastomosis groups (AG) of $R$. solani (Rs) and genotypes of $R$. oryzae (Ro) were assigned using Q-PCR and/or cluster analysis data, as described in the text.

d Method used for initial identification in validation experiments; ITS, ITS sequence was matched to annotated GenBank accessions using Blastn (1). 
archived in a permanent laboratory collection. Morphology of the mycelia and microsclerotia were examined using compound and dissecting microscopes (Scientific Instrument Co., Sunnyvale, CA). Nuclei were stained with $0.05 \%$ aqueous Trypan Blue and observed using a light microscope at 400x magnification. AG-8 isolate C1 (48), AG-2-1, and AG-10 tester isolates, designated AG-2-1R and AG-10R, were obtained from M. Mazzola, USDAARS, Wenatchee, WA. Twenty-five $R$. solani isolates identified by Q-PCR and authenticated by Blastn comparisons of ITS sequences are indicated as "Q-PCR" under identification method in Table 1; four isolates for which ITS sequence data were obtained prior to Q-PCR are indicated as "ITS" in Table 1.

DNA from 26 soilborne species prevalent in PNW soils and/or pathogenic to wheat was used to test primer specificity. The species used are as follows: Aphanomyces euteiches Dreschler isolate Ae02A9; Bipolaris sorokiniana (Sacc.) Shoemaker isolate BS15e-99; Cephalosporium gramineum Y. Nisikado \& Ikata isolate 95-4; Fusarium culmorum (Smith) Sacc. isolate F070366; F. pseudograminearum O'Donnell \& Aoki isolate 006-13; Gaeumannomyces graminis var. tritici Walker isolate R3-111a-1; Mortierella hyalina (Harz) W. Gams isolate P2c3; Phytophthora infestans (Mont.) de Bary isolate W03GE; Puccinia striiformis $\mathrm{f}$. sp. tritici Westend isolate PST100; Pyrenophora teres Drechs. f. teres Smedeg isolate ND89-19; P. tritici-repentis (Died.) Drechsler isolate Pti2; Pythium abappressorium Paulitz \& Mazzola; P. irregulare Buisman grp. I isolate 0900101; P. irregulare Buisman grp. IV isolate 020155; P. ultimum Trow isolate 030141; Rhizoctonia cerealis Hoeven; $R$. solani AG-3 isolate ST-41; $R$. solani AG-K isolate M63268; $R$. solani AG-R isolate Z27-AM; Stagnosporum nodorum isolate $\mathrm{Sn} 2 \mathrm{k}$; Tapesia acuformis

TABLE 1. (Continued from preceding page)

\begin{tabular}{|c|c|c|c|c|c|c|}
\hline Isolate & Location $^{\mathrm{a}}$ & $\operatorname{Host}^{b}$ & Group $^{c}$ & GB accession & Identification method $^{\mathrm{d}}$ & Reference \\
\hline 110508 & CAF Pullman & Lentil & AG-10 & & & This study \\
\hline 110519 & CAF Pullman & Lentil & AG-2-1 & & & This study \\
\hline 110532 & CAF Pullman & Lentil & AG-10 & & & This study \\
\hline 070340 & PCFS Pullman & WW & AG-10 & & Q-PCR & This study \\
\hline 120202 & PCFS Pullman & SW & AG-2-1 & & & This study \\
\hline 120205 & PCFS Pullman & SW & AG-2-1 & & ITS & This study \\
\hline 120215 & PCFS Pullman & SW & AG-2-1 & & & This study \\
\hline 120229 & PCFS Pullman & SW & AG-10 & & Q-PCR & This study \\
\hline 120244 & PCFS Pullman & SW & AG-3 & & Q-PCR & This study \\
\hline 120246 & PCFS Pullman & SW & AG-10 & & Q-PCR & This study \\
\hline 120248 & PCFS Pullman & SW & AG-10 & & Q-PCR & This study \\
\hline 120251 & PCFS Pullman & SW & AG-2-1 & & Q-PCR & This study \\
\hline 040560 & Ritzville, WA & SW & AG-I-like & & & This study \\
\hline 040561 & Ritzville, WA & SW & AG-I-like & & & This study \\
\hline 040562 & Ritzville, WA & SW & AG-2-1 & & & This study \\
\hline 040563 & Ritzville, WA & SW & AG-I-like & & & This study \\
\hline 040565 & Ritzville, WA & SW & AG-I-like & & & This study \\
\hline 040571 & Ritzville, WA & SW & AG-I-like & & & This study \\
\hline 050579 & Ritzville, WA & MF & AG-8 & & & This study \\
\hline 050580 & Ritzville, WA & SW & AG-8 & & & This study \\
\hline 050585 & Ritzville, WA & $\mathrm{CF}$ & AG-2-1 & & & This study \\
\hline 070533 & Ritzville, WA & MF & AG-8 & & & This study \\
\hline 070534 & Ritzville, WA & $\mathrm{CF}$ & AG-8 & & & This study \\
\hline 070535 & Ritzville, WA & $\mathrm{CF}$ & AG-8 & & & This study \\
\hline 070539 & Ritzville, WA & $\mathrm{CF}$ & AG-8 & & & This study \\
\hline 070578 & Ritzville, WA & MF & AG-8 & & & This study \\
\hline 100279 & Walla Walla, WA & $\mathrm{CP}$ & AG-10 & & & This study \\
\hline 100280 & Walla Walla, WA & $\mathrm{CP}$ & AG-10 & & & This study \\
\hline \multicolumn{7}{|c|}{ Other $R$. oryzae } \\
\hline 030111 & Albion, WA & Pea & III & & & 35 \\
\hline $4-3-6$ & Duffy, WA & SB & III & & & 28 \\
\hline 070383 & Lewiston, ID & WW & II/III & & & This study \\
\hline 070385 & Lewiston, ID & WW & II/III & & & This study \\
\hline $1-6-1$ & Lind, WA & SB & III & & & 28 \\
\hline 070322 & Lind, WA & WW & I & & & This study \\
\hline 0801305 & PF Garfield & SB & II/III & & & 35 \\
\hline 1202113 & PF Garfield & SB & None & & & This study \\
\hline 1202119 & PF Garfield & $\mathrm{W}$ & III & & & This study \\
\hline 120277 & Mockonema, WA & SB & I & & & This study \\
\hline 120286 & Mockonema, WA & SB & I & & & This study \\
\hline 120287 & Mockonema, WA & SB & None & & Q-PCR & This study \\
\hline 030109 & Palouse, WA & Fescue & II/III & & & 35 \\
\hline $3-2-6$ & PNW & & III & & & 28 \\
\hline 080013 & CAF Pullman & SB & II/III & & ITS & This study \\
\hline 080015 & CAF Pullman & SB & II/III & & ITS & This study \\
\hline 080324 & CAF Pullman & SB & II/III & & & This study \\
\hline 080329 & CAF Pullman & SB & I & & & This study \\
\hline 080031 & CAF Pullman & SB & II/III & & & 35 \\
\hline 080042 & CAF Pullman & SB & II/III & & & 35 \\
\hline 1202126 & CAF Pullman & SW & II/III & & & This study \\
\hline 1202128 & CAF Pullman & SW & I & & & This study \\
\hline 120254 & PCFS Pullman & SW & $\mathrm{I}$ & & & This study \\
\hline $2-3-1$ & Hermiston, OR & W & III & & & 28 \\
\hline $2-3-2$ & Hermiston, OR & $\mathrm{W}$ & III & & & 28 \\
\hline $3-3-2$ & Pendleton, OR & SB & II/III & & & 28 \\
\hline $3-3-5$ & Pendleton, OR & $\mathrm{B}$ & III & & & 28 \\
\hline
\end{tabular}


(Boerema, R. Pieters \& Hamers) Crous isolate 99-23-3; T. yallundae Wallwork \& Spooner isolate 99-31-1; Tilletia controversa (Kühn) Kawchuk isolate 282. T. laevis Kühn (1873) isolate 90-61; Trichoderma polysporum (Link) Rifai isolate P1cc9; and T. viride Lieckfeldt isolate W3b4. Organisms were cultured on PDA with the exception of Phytophthora infestans, which was maintained on corn meal agar (47).

DNA isolation from culture and soil. Mycelia were cultured in potato dextrose broth for up to 7 days, transferred to a Buchner funnel lined with a Whatman No. 1 filter disk, and washed three times with sterile distilled water under gentle vacuum. Total (genomic and mitochondrial) DNA was obtained from fresh or lyophilized mycelia using the FastDNA Kit (QBIOgene, Carlsbad, CA) and FastPrep FP120 homogenizer (QBIOgene) according to the manufacturer's protocol (35). DNA was quantified using the Fluorescent DNA Quantitation Kit (Bio-Rad, Hercules, CA) and Safire fluorometric plate reader (TECAN, Research Triangle Park, NC).

To analyze pathogen DNA in soils, triplicate 0.5 -g (fresh weight) samples were extracted using the UltraClean Soil DNA Kit (MO BIO Laboratories, Solana Beach, CA) and the FastPrep FP120 homogenizer (QBIOgene) at a setting of " 5 " for two to four 45-s intervals. Inhibitor removal solution was added for improved extraction efficiency as recommended by the manufacturer. After elution from columns, the extracts were treated with insoluble polyvinylpyrrolidone (PVP, Sigma Chemical Co., St. Louis, MO) to remove humic acids and other inhibitors of PCR. For each extract, $50 \mu \mathrm{l}$ of an aqueous suspension of $10 \%$ PVP (wt/vol) was concentrated by centrifugation, and the PVP pellet was suspended in the soil extract for 2 to $3 \mathrm{~min}$ at room temperature. Subsequently, the PVP was separated from the extract by centrifugation before Q-PCR analysis.

Average soil dry weights were obtained from duplicate $10-\mathrm{g}$ samples incubated at $100^{\circ} \mathrm{C}$ for 48 to $50 \mathrm{~h}$. The dry weight/wet weight ratio for each soil was used to calculate dry weights of extracted soils.

ITS sequencing, alignments, and cluster analysis. All ITS sequences were comprised of ITS1, 5.8S rDNA and ITS2, flanked by the $3^{\prime}$ end of the $18 \mathrm{~S}$ rDNA and $5^{\prime}$ end of the $28 \mathrm{~S}$ rDNA. Rhizoctonia ITS DNA was amplified from purified fungal DNA using PCR and ITS1 and ITS4 primers (52). PCR reactions consisted of 75 to $180 \mathrm{ng}$ of fungal DNA, $1.5 \mathrm{mM} \mathrm{MgCl}_{2}, 0.2 \mathrm{mM}$ of each deoxynucleotide, $10 \mathrm{pmol}$ of each primer, and $0.5 \mathrm{U}$ of Taq polymerase (Promega Corp., Madison, WI) in a total volume of $50 \mu \mathrm{l}$. PCR was performed using the PTC-200 thermocycler (MJ Research, Reno, NV) at $94^{\circ} \mathrm{C} 3 \mathrm{~min}\left(1\right.$ cycle); $94^{\circ} \mathrm{C} 45 \mathrm{~s}$, $58^{\circ} \mathrm{C} 60 \mathrm{~s}, 72^{\circ} \mathrm{C} 60 \mathrm{~s}(25$ cycles $) ; 72^{\circ} \mathrm{C} 10 \mathrm{~min}(1$ cycle $) ; 4^{\circ} \mathrm{C}$ soak. Amplicons were separated from excess nucleotides and salts using agarose gel electrophoresis, the PCR Cleanup Kit (Qiagen, Inc., Valencia, CA), the DNA Nucleotide Removal Kit (Qiagen, Inc.), or ExoSAP-IT (USB Corp., Cleveland, OH).

ITS polymorphism within certain $R$. oryzae isolates harboring two types of ITS sequences (genotype II/III) necessitated the cloning of the amplicons prior to sequencing. Amplicons were generated as described for $R$. solani, ligated to pCR2.1 using the TA Cloning Kit (Invitrogen Life Technologies, Carlsbad, CA), and mobilized into E. coli INV $\alpha$ F' competent cells as recommended by the manufacturer. Recombinants were selected using the Invitrogen X-gal protocol. Plasmid DNA was obtained using the Spin Miniprep Kit (Qiagen, Inc.).

Approximately $100 \mathrm{ng}$ of amplified $R$. solani ITS DNA or $100 \mathrm{pg}$ of cloned $R$. oryzae ITS DNA were subjected to cycle sequencing using primers ITS1 (52), ITS4 (52), 5.8UP 5'CTTGCGCTCCTTGGTATTC, 5.8LO 5'CGATGCGAGAGCCAAGAG and either the Beckman CEQ 8000 and CEQ Dye Terminator Cycle Sequencing Quick Start kit (Beckman Coulter, Inc., Fullerton, CA) or ABI Big Dye chemistry (Applied Biosystems, Foster City, $\mathrm{CA}$ ). The cycling program for the CEQ Dye Terminator system was $96^{\circ} \mathrm{C} 20 \mathrm{~s}, 50^{\circ} \mathrm{C} 20 \mathrm{~s}, 60^{\circ} \mathrm{C} 4$ min $(30$ cycles $)$, and $4^{\circ} \mathrm{C}$ soak. ABI Big Dye sequencing was carried out at the Laboratory for Biotechnology and Bioanalysis, Washington State University, Pullman.

ITS nucleotide sequences were assembled using Lasergene SeqMan II version 5.00 software (DNASTAR, Inc., Madison, WI). ITS sequences from PNW isolates, AG-8 C1 (48), AG-2-1R, AG-10R (M. Mazzola, USDA-ARS, Wenatchee, WA), and annotated GenBank accessions were compared using Blastn (1) and used for AG assignment. Sequences were aligned using ClustalW 1.8 (16) and sequence differences were visualized using GeneDoc Shading Utility version 2.6.002 (Pittsburgh Supercomputing Center, Pittsburgh, PA).

Cluster analysis was performed using 5.8S-ITS2 sequence data obtained from our reference isolates and GenBank accessions of $R$. solani isolates (35 sequences), binucleate Rhizoctonia spp. (nine sequences), and $R$. oryzae (10 sequences). Sequences were sorted by species and AG, aligned using ClustalW 1.8 (16), and subjected to bootstrap analysis (1,000 replicates) using the neighbor-joining method of Phylip version 3.65 (11) and Kimura parameter- 2 correction. Clusters were visualized using TreeView version 1.6.6. (33). Branches sustaining bootstrap support values of less than 70 were collapsed. AG-2-2 isolate A4 (GenBank AF308621), Ceratobasidium sp. AG-A isolate Str75 (GenBank DQ102426), and Waitea circinata isolate TOM-BFW (GenBank AB213577) were used to root the $R$. solani, binucleate Rhizoctonia and $R$. oryzae trees, respectively.

Primer design and in silico analyses. $R$. solani isolates used for primer design (Table 1) were as follows: 120202, 120208, 1202265, and 1202325 (AG-2-1); 070304, 070307, 070308, 120281, and C1 (AG-8); 100249, 100250, and 1202334 (binucleate); and 100279100280,120203 (AG-10). R. oryzae isolates used were 120232 (I), Ro4 (II), 070383 (II/III), and 0801344 and 0801387 (III). Design criteria were as follows: (i) minimum oligonucleotide length of 16 bases; (ii) gas chromatographic (GC) content of 0.4 to 0.6 ; (iii) melting temperatures of 58 to $72^{\circ} \mathrm{C}$ determined by the nearest neighbor thermodynamic values method, and no more than a $3^{\circ}$ difference between the primers of each pair; (iv) $5^{\prime}$ and $3^{\prime}$ terminal $\mathrm{G}$ or $\mathrm{C}$; and (v) no significant dimer formation $(\Delta \mathrm{G}$ of -4.5 or greater) as indicated by GeneRunner version 3.05 (Hastings Software, Inc., Hudson, NY) and OLIGO version 6.65 (Molecular Biology Insights, Cascade, CO). Oligonucleotides were synthesized by MWG Biotech (High Point, NC), OPERON Technologies (Alameda, CA), Qiagen, or Invitrogen (Carlsbad, CA). For each group of isolates, up to five forward primers were designed from the ITS1 region and five reverse primers were designed from ITS2. The most sensitive and efficient primer pairs were used for Q-PCR (Table 2).

To determine if nontarget DNA could be distinguished from target DNA by primer hybridization thermodynamics in silico, primer-template duplex stabilities were evaluated for each primer and ITS sequences from PNW reference isolates (Table 2) or Rhizoctonia GenBank accessions. The latter included 46 R. solani accessions representing 12 AGs, 26 binucleate Rhizoctonia (teleomorph Ceratobasidium) accessions representing 16 AGs, seven $R$. oryzae accessions, twelve accessions of other Rhizoctonia spp., seven accessions of other Ceratobasidium spp., two Athelia spp., and two Ceratorhiza oryzae-sativa. Duplex stability values were generated using the nearest neighbor algorithm of PrimerSelect 5.00 (DNASTAR, Inc., Madison, WI). Default parameters for the calculation of $\Delta \mathrm{G}$ of stabilities were $50 \mathrm{mM}$ salt (common in PCR buffers), $25^{\circ} \mathrm{C}$ and an average stability cut-off of $0.76 \mathrm{kcal} /$ $\mathrm{mol} / \mathrm{bp}$.

Q-PCR assays. Real-time PCR was conducted using the capillary-based LightCycler thermocycler and FastStart DNA Master SYBR Green I chemistry (Roche Applied Science, Indianapolis, IN). Each PCR sample contained $10 \mathrm{fg}$ to $100 \mathrm{pg}$ of target DNA, 5 pmol of each primer, and $4 \mathrm{mM} \mathrm{MgCl}_{2}$. Reaction volumes were $10 \mu \mathrm{l}$ for $0.5 \mu \mathrm{l}$ of purified fungal DNA and $20 \mu \mathrm{l}$ 
for $1 \mu \mathrm{l}$ of soil or root extracts spiked with fungal DNA. The amplification program consisted of $95^{\circ} \mathrm{C} 10$ min followed by up to 50 cycles of $95^{\circ} \mathrm{C} 5 \mathrm{~s}, 57$ to $63^{\circ} \mathrm{C} 10 \mathrm{~s}, 72^{\circ} \mathrm{C} 10 \mathrm{~s}$. Annealing temperatures are given in Table 2. Fluorescence was monitored after each annealing step. Amplicon melting profiles were generated by increasing the temperature of the reaction from 70 to $96^{\circ} \mathrm{C}$ (default of 0.1-degree increments for temperature and 0.4 to 0.5 -degree intervals for fluorescence). "No DNA" (negative) controls contained autoclaved nano-grade water instead of DNA extracts. Primer pairs exhibiting the greatest endpoint fluorescence and a single product in melting profile analyses (Table 2) were selected for further testing. All samples in this study were amplified in duplicate or triplicate. Pathogen DNA was expressed as nanogram or picogram per gram dry weight of soil.

To test the performance of each primer pair in a DNA mixture, target DNA was held constant at the quantification limit $(\mathrm{Ct} \approx 33)$, usually 2 to $20 \mathrm{fg}$ of mycelial DNA depending upon the primer pair, in the presence of increasing molar ratios (1 to $\left.10^{5}\right)$ of mycelial DNA from the other nontarget Rhizoctonia isolates. Performance was evaluated on the basis of amplification of only the target DNA, as indicated by amplicon melting profile.

Mycelial root and soil standard curves. Total DNA from the following isolates was used to construct the standard curves for this study: 100249 and 100250 (AG-I-like); 120202, 120208, and 12020265 (AG-2-1); C1, 070304, and 070308 (AG-8); 100278 and 120203 (AG-10); 120232 (R. oryzae genotype I); 070322, 070383 , and 070385 ( $R$. oryzae genotype II/III); and 0801344 and 0801387 ( $R$. oryzae genotype III). Cloned Ro4-4 ITS DNA was used to test $R$. oryzae genotype II primers. Each standard curve was generated using five 10-fold serial dilutions of cultured mycelial DNA in nanograde water, soil extracts or root extracts (described in the next paragraph). Ten picograms to $1 \mathrm{fg}$ of DNA was used for the mycelial standard curves.

Root extracts for standard curves were obtained from 14-dayold seedlings of the hexaploid wheat cultivar Scarlet. Roots were gently removed from soil, washed, and stored at $-20^{\circ} \mathrm{C}$. Frozen tissue (500 to $600 \mathrm{mg}$ ) was ground to a fine powder in liquid nitrogen using a chilled mortar and pestle. Approximately $100 \mathrm{mg}$ of homogenized tissue was extracted using the UltraClean Soil DNA Kit (MO BIO Laboratories) and the FastPrep FP120 homogenizer essentially as described for soil samples, except that acid-washed Amberlite XAD-4 (100 mg per $100 \mathrm{mg}$ of tissue; Sigma Chemical Co.) was added at the start of extraction to reduce conjugation of DNA with phenolic compounds, and the PVP treatment was omitted. Soil extracts were made from take-all decline (TAD) soils from Lind, Mount Vernon, and Quincy, WA, and from an agricultural soil from Fargo, ND (43). Root and soil standard curves were generated using root and soil extracts spiked with $100 \mathrm{pg}$ to $10 \mathrm{fg}$ of fungal DNA.

To relate $\mathrm{Ct}$ to propagules of $R$. solani AG-8 per gram of soil (ppg), a separate standard curve was generated. Autoclaved oats (37) colonized with $R$. solani AG-8 isolates 050579,050533 , and 120281 (Table 1) were homogenized using a coffee grinder, and ground inocula were sieved through 1 - and 0.25 -mm-opening sieves to obtain particle sizes of 250 to $1,000 \mu \mathrm{m}$. Inocula were enumerated from a suspension of $100 \mathrm{mg}$ of homogenized material in $5 \mathrm{ml}$ of water and from a 10-fold dilution of the suspension. Triplicate $0.2-\mathrm{ml}$ aliquots of each dilution were spread onto water agar supplemented with chloramphenicol at $100 \mu \mathrm{g} / \mathrm{ml}$ and $1 \mu \mathrm{g} / \mathrm{ml}$ a.i. benomyl (Benlate, DuPont, Wilmington, DE), and incubated at $24^{\circ} \mathrm{C}$ in darkness for 3 days. Population density was calculated as the average of means of the undiluted and 1:10 suspensions. Ten to $1,000 \mathrm{ppg}$ were thoroughly mixed into pasteurized nonagricultural soil from Quincy, WA (43) that carried no detectable endogenous populations of Rhizoctonia. Quincy soil is typical of PNW fields that sustain yield losses from Rhizoctonia spp. Triplicate 0.5 -g (fresh weight) aliquots of soil were immediately collected and DNA extractions were immediately carried out using the MoBio UltraClean Soil extraction kit (MO BIO Laboratories). Amplification efficiencies were calculated using the equation $10^{1 /-m}-1$, where $\mathrm{m}$ is slope of the plot of $\log$ DNA versus cycle threshold (Ct) (12).

Agricultural soil samples. Soils (100 to $200 \mathrm{~g}$ per sample) were collected in 2005 and 2006 from Rhizoctonia bare patches in fallow and cropped research plots from a long-term cropping system study at a farm in Ritzville, WA. The system included plots of continuously cropped spring wheat, and plots that were chemically fallowed with herbicide or fallowed with inverted sweeps and rod weedings. Soil samples were stored at $-20^{\circ} \mathrm{C}$ prior to DNA extraction. Samples were thoroughly homogenized by crushing and mixing, and triplicate 0.5 -g aliquots were extracted as described in DNA isolation from culture and soil.

\section{RESULTS}

PNW R. solani ITS sequences. The 68 PNW R. solani isolates used in this study (Table 1) were selected from our collection of over 2,000 Rhizoctonia isolates on the basis of host origin and location. Four ITS groups were prevalent among the isolates; representatives of each group were designated as reference isolates and assigned GenBank accession nos. DQ356407 to DQ356413 (Table 1). The isolates were assigned to AG groups 2-

TABLE 2. Real-time polymerase chain reaction primers and assay specifications for the quantification of Rhizoctonia solani, $R$. oryzae, and binucleate Rhizoctonia (teleomorph Ceratobasidium)

\begin{tabular}{|c|c|c|c|c|c|c|}
\hline Target & Primer & Sequence $\left(5^{\prime}\right.$ to $\left.3^{\prime}\right)$ & Position $^{\mathrm{a}}$ & Annealing temp. $\left({ }^{\circ} \mathrm{C}\right)^{\mathrm{b}}$ & Melting temp. $\left({ }^{\circ} \mathrm{C}\right)^{\mathrm{b}}$ & Amplicon (bp) \\
\hline $\begin{array}{l}\text { R. solani AG2-1 } \\
\text { and AG-8 }\end{array}$ & $\begin{array}{l}\text { Rs } 2.1 / 8 \mathrm{~F} \\
\text { Rs } 2.1 / 8 \mathrm{R}\end{array}$ & $\begin{array}{l}\text { GTTGTAGCTGGCCCATTCATTTG } \\
\text { GAGCAGGTGTGAAGCTGCAAAAG }\end{array}$ & 14 & 63 & 84.2 & 441 \\
\hline R. solani AG-8 & $\begin{array}{l}\text { Rs8F } \\
\text { Rs8R }\end{array}$ & $\begin{array}{l}\text { GGGGGAATTTATTCATTTATTGGAC } \\
\text { GGTGTGAAGCTGCAAAAG }\end{array}$ & 93 & 58 & 84.0 & 327 \\
\hline R. solani $\mathrm{AG}-10$ & $\begin{array}{l}\text { Rs10F } \\
\text { Rs10R }\end{array}$ & $\begin{array}{l}\text { GTAGCTGGCCTCTTAATTTG } \\
\text { CAAGTGTGAACCTGCAAGAC }\end{array}$ & 17 & 60 & 84.0 & 432 \\
\hline Binucleate & $\begin{array}{l}\text { CeBF } \\
\text { CeBR }\end{array}$ & $\begin{array}{l}\text { GGACTTGGGGGTCTGC } \\
\text { CGGCCACCTTTTTTACG }\end{array}$ & 410,419 & 57 & 85.3 & 123 \\
\hline $\begin{array}{r}\text { R.oryzae } \\
\text { geno II }\end{array}$ & $\begin{array}{l}\text { RoGr2F } \\
\text { RoGr2R }\end{array}$ & $\begin{array}{l}\text { CTCTGTTTCAAACGGGTTTACTACG } \\
\text { TCCAAGTCCAAATACAACAATTAAAG }\end{array}$ & 91 & 60 & 83.0 & 289 \\
\hline $\begin{array}{l}\text { R. oryzae } \\
\text { geno III }\end{array}$ & $\begin{array}{l}\text { RoGr3F } \\
\text { RoGr3R }\end{array}$ & $\begin{array}{l}\text { CTGTTGAAACCGGTTTACTATG } \\
\text { CTTCCAAGTCCAAATACAACAATC }\end{array}$ & 126 & 60 & 82.5 & 286 \\
\hline
\end{tabular}

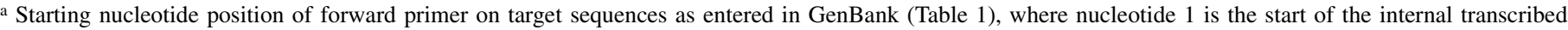
spacer 1 (ITS1) sequence.

b Annealing temperatures and amplicon melting temperature maxima were determined using purified mycelial DNA. 
$1,8,10$, and AG-I-like (binucleate) on the basis of nucleotide sequence identity (Blastn E values of 0.0) with GenBank accessions from the United States, Australia, UK, Italy, Japan, and other countries (Fig. 1). Isolates 070304, 070307, 070308, 120281, and 1202262 previously were identified as AG-8 in amplified fragment length polymorphism (AFLP) genotyping studies (K. Adams and T. Paulitz, unpublished data). These isolates shared $100 \%$ ITS sequence identity to one another and to the AG-8 tester isolate C1. A fourth group of Rhizoctonia were binucleate and had the highest (96\%) ITS sequence identity with Rhizoctonia sp. isolates Eab-S2 (AJ242882) and Eab-S4 (AJ242884) from Spain. The accessions from Spain were not annotated with respect to AG but they harbored exact binding sites for primers $\mathrm{CeBF}$ and CeBR (Table 2). The PNW binucleates also shared $94 \%$ identity with three AG-I isolates, AV-2 from the horticultural plant Artemisia (Japan, AB196650), AV-2 from Pinus sylvestris (Finland, AJ419932), and Ibs1 from

\section{A}

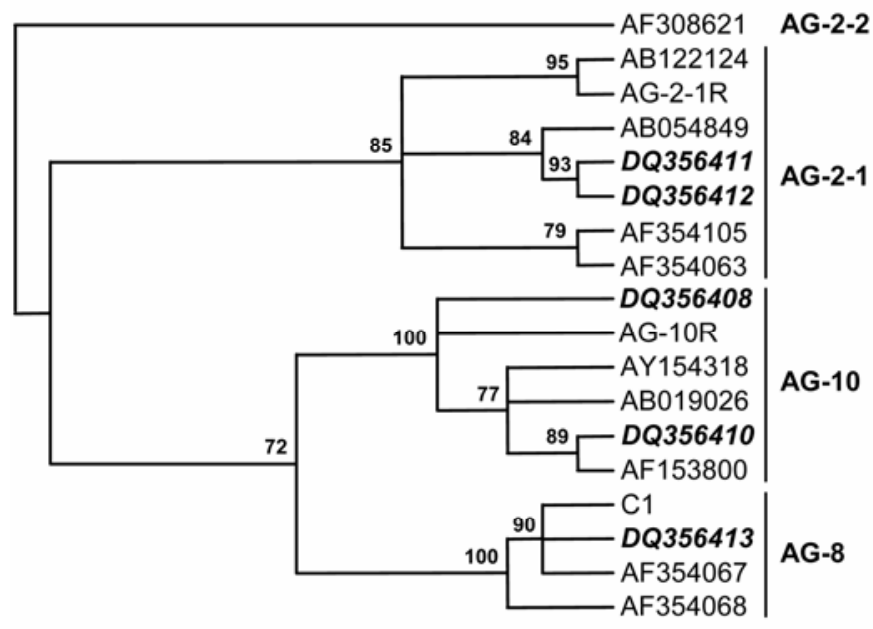

B

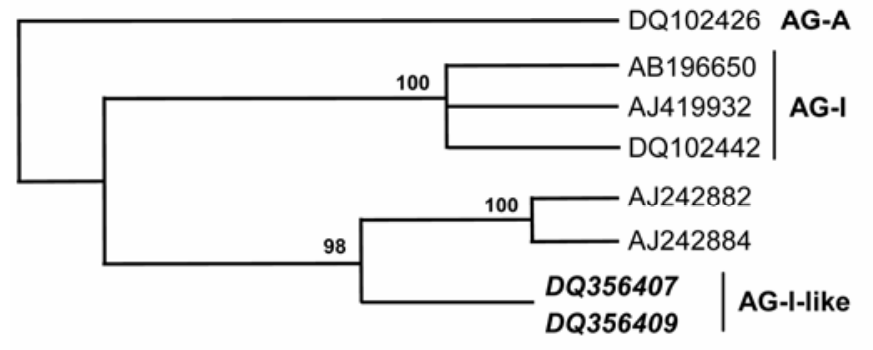

C

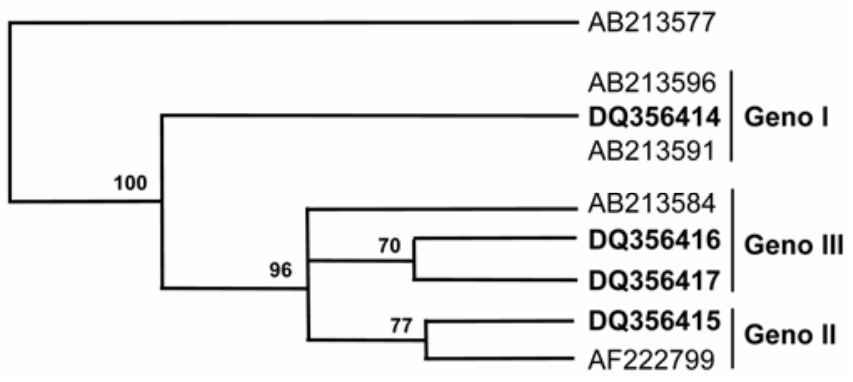

Fig. 1. Cluster analysis of the 5.8S-internal transcribed spacer 2 sequences of Pacific Northwest isolates of A, Rhizoctonia solani, B, binucleate Ceratobasidium, $\mathbf{C}, R$. oryzae, and selected GenBank accessions. Isolate names and origins are listed in Table 3. Distances are bootstrap values (1,000 replicates) obtained using the neighbor-joining method of Phylip version 3.65 (11). Clusters were visualized using TreeView vers. 1.6.6. (33). Outgroups for A, B, and $\mathrm{C}$ were $R$. solani AG-2-2 isolate A4 (AF308621), Ceratobasidium AG-A isolate Str75 (DQ102426), and Waitea circinata isolate TOM-BFW (AB213577), respectively. strawberry (Israel, DQ102442). In contrast, the AG-I accessions lacked priming sites for CeBF and CeBR (Table 2) which were developed to identify Ceratobasidium sp., suggesting that the PNW Ceratobasidium sp. was not a true AG-I. ITS1-5.8S-ITS2 sequences from PNW isolates of the same AG displayed 98.0 to $99.5 \%$ identity, and identities between groups were about $82 \%$ but as high as $95 \%$ for AG-2-1 and AG-8. The PNW isolates displayed more ITS1-5.8S-ITS2 sequence conservation than that reported by Kuninaga et al. (19), 66 to $100 \%$ within the same AG and 55 to $96 \%$ among different AG for subgroup.

ITS sequences of the isolates also were aligned using Clustal and grouped using Phylip (cluster analyses). ITS2 was more conserved among members of the same AG compared to ITS1, and 5.8S-ITS2 was considered to be most suitable for comparing these sequences. The PNW R. solani sorted into four 5.8S-ITS2 monophyletic groups (Fig. 1A and B). PNW isolates DQ356411 and DQ356412 clustered with an AG-2-1 accession from Japan (AB054849), and formed a well-supported clade that included the AG-2-1 reference strain (AG-2-1R) and other AG-2-1 isolates from Japan (AB122124, AF354105) and Australia (AF354063) (Fig. 1A). PNW isolates DQ356408 and DQ356410 grouped with the AG-10 reference strain (AG-10R), and AG-10 isolates from Brazil (AY154318), Japan (AB019026), and Australia (AF153800) (Fig. 1A). The PNW isolate DQ356413 clustered with the AG-8 reference strain C1 and AG-8 isolates from Australia (AF352067, AF364068). PNW isolates DQ356407 and DQ356409 were most similar to two Rhizoctonia sp. from Spain (AJ242882 and AJ242884), and shared identity with AG-I isolates from Israel (DQ102442), Finland (AJ419932), and Japan (AB196650) (Fig. 1B).

Identification based on Q-PCR was consistent with Blastn analyses of ITS sequences in GenBank for the core set of 28 PNW Rhizoctonia isolates that were tested. Twenty-three $R$. solani isolates (Q-PCR in Table 1) identified by Q-PCR were authenticated by Blastn comparisons. For an additional five isolates (ITS in Table 1), ITS sequence data were authenticated by Q-PCR.

PNW R. oryzae ITS sequences. A core set of 13 PNW isolates (070322, 070383, 070385, 080324, 080329, 0801344, 0801387, 120254, 120277, 120286, 1202119, 1202126, and 1202128), identified as $R$. oryzae on the basis of morphology and hyphal growth on PDA, sorted into three ITS sequence groups or genotypes, designated I, II, and III. Sequence identities among the $R$. oryzae genotypes varied from 96.2 to $98.8 \%$; identities between groups ranged from 87 to $97 \%$. Five isolates were of genotype I, four of genotype III, and three exhibited ITS sequences of both genotypes II and III (Table 1). None of the 29 total $R$. oryzae isolates displayed only genotype II. $R$. oryzae isolates 030109 , 030111, 080031, 080042, 0801305, 0801344, and 0801387, known to be pathogenic to barley and wheat (39), were identified as genotypes II/III or III in the Q-PCR assays (Table 1). Reference isolates of $R$. oryzae were assigned GenBank accession numbers DQ356414 to DQ356417 (Table 1).

In Blastn (1) analyses, ITS of genotypes I, II, and III showed 88 , 96, and $98 \%$ sequence identity to a set of $W$. circinata var. circinata isolates from annual bluegrass (9). Genotypes I and III were further distinguished by identity to Waitea circinata var. circinata from turfgrass soils (49) from the United States (AB213591, AB213597) and creeping bentgrass from Japan (AB213583, AB213584), respectively. In contrast, genotype II was more similar to $R$. zeae of Poa from Canada (AF222799). Phylogenetic analysis using 5.8S-ITS2 sequence data (Fig. 1C) showed that genotypes II and III formed two loosely supported clades with $W$. circinata var. circinata from Japan (AB213584) and the $R$. zeae, whereas genotype I formed a strongly supported clade with other $W$. circinata var. circinata isolates from Japan (AB213591, AB213596).

Assay specificity. Several combinations of forward and reverse primers for each target Rhizoctonia group or genotype were tested 
to select the pair that performed with the greatest degree of specificity, sensitivity and efficiency (Table 2). Optimal annealing temperatures, amplicon melting points (Tm), and deduced amplicon sizes are listed in Table 2.

Primers Rs2.1/8F and Rs2.1/8R amplified both $R$. solani AG-21 and AG- 8 with equal efficiency (Table 3 ). These primers were redesigned as extensions of an original pair (Rs2.1F, 5'GTTGTAGCTGGCCCATTC and Rs2.1R, 5'GGTGTGAAGCTGCAAAAG). Although the original pair conferred specificity to $R$. solani AG-2-1, they had a lower amplification efficiency. The extended primers increased efficiencies from $0.78,0.75$, and 0.76 to 0.92 , 0.94 , and 0.92 for genomic, soil, and root extracts of AG-2-1 DNA, respectively. $R$. solani AG-2-1 was distinguished from AG8 because it failed to amplify with primers Rs8F and Rs8R, highly specific to AG-8. Likewise, diagnosis of the $R$. oryzae genotypes II/III and III was made on the basis of differential amplification in the II and III assays.

The Q-PCR assays did not amplify DNA from 26 nontarget soilborne fungi and oomycetes pathogenic to wheat and/or found in PNW soils. Observed $\mathrm{Ct}$ values for these templates were not significantly different than those for water controls. For cases in which $\mathrm{Ct}$ values were relatively low, such as the "binucleate" primers and Aphanomyces eutiches, melting profile analyses indicated that target (specific) amplicons were not generated. Likewise, the $R$. solani assays did not amplify any of the $R$. oryzae DNA, and vice versa.

In DNA mixing experiments, primer specificity was tested by amplifying the target DNA at concentrations near the detection limit in the presence of up to $10^{5}$ molar excess of all other nontarget Rhizoctonia DNA. In such mixtures, $R$. solani target DNA was reliably quantified at about 2 to $17 \mathrm{fg}$, and $R$. oryzae at 30 to $97 \mathrm{fg}$ (Table 4), depending upon the assay. Performance in DNA mixtures was dependent upon primer sequence and relatedness among ITS groups or genotypes; the AG-2-1 assay was most prone to interference by $R$. solani AG- 8 . With the exception of the AG-2-1 primers discussed previously, the primers were specific to AG or genotype.

To expand specificity studies to additional Rhizoctonia that could not be obtained in culture, an in silico analysis was conducted using Rhizoctonia and related GenBank accessions. Specific annealing was indicated by duplex stability $(\Delta \mathrm{G})$ values of less than $-33 \mathrm{kcal} / \mathrm{mol}$. $\Delta \mathrm{G}$ values for the primers and their PNW target DNAs ranged from -33.1 to $-46.5 \mathrm{kcal} / \mathrm{mol}$. For instance, primers Rs2.1F and Rs2.1R formed duplexes at -33.7 to $-34.9 \mathrm{kcal} / \mathrm{mol}$ with annotated $R$. solani AG-2-1 isolates from Japan, Norway, and The Netherlands, and Rs8F and Rs8R formed duplexes at -33.7 to $-46.5 \mathrm{kcal} / \mathrm{mol}$ with $R$. solani $\mathrm{AG}-8$ isolates from Australia, Brazil, and the United Kingdom. $R$. oryzae primers formed strong duplexes ( -33.3 to $-43.7 \mathrm{kcal} / \mathrm{mol}$ ) with $W$. circinata var. circinata accessions from the United States, Canada, Japan, and the United Kingdom. The $\Delta \mathrm{G}$ values also predicted whether these accessions were genotype I, II/III, or III.

In contrast, duplex stability values for nontarget AG isolates ranged from -12.4 to $-32.6 \mathrm{kcal} / \mathrm{mol}$, and only the forward or reverse primer (but not both of a pair) formed a nonspecific hybrid. Amplification in our PCR assays was not predicted for the following nontarget Rhizoctonia: Thanatephorus cucumeris accessions representing AG-1, 1-IA, 1-IB, 1-IC, 2, 2-2, 2-t, 2-3, 3, 4, 4 HG-I, 5, 6, 6-GV, 6-HG-I, 7, 9, 11, and 12; Ceratobasidium accessions representing AG-A, BI, Ba, Bo, D, D-I, F, G, H, K, L, $\mathrm{O}, \mathrm{P}, \mathrm{Q}, \mathrm{R}, \mathrm{S}, \mathrm{T}$, and $\mathrm{U} ;$ Rhizoctonia bataticola, cerealis, crocorum, and violacea; Thanatephorus praticola; Ceratobasidium albasitensus, anceps, augustisporum, bicorne, cereale, cornigerum, papillatum, ramicola, and stevenesii; Athelia arach-

TABLE 3. Standard curve constants $(\mathrm{m}, \mathrm{b})^{\mathrm{a}}$ and amplification efficiencies for Rhizoctonia quantitative-polymerase chain reaction (Q-PCR) assays of mycelial, soil and root extracts

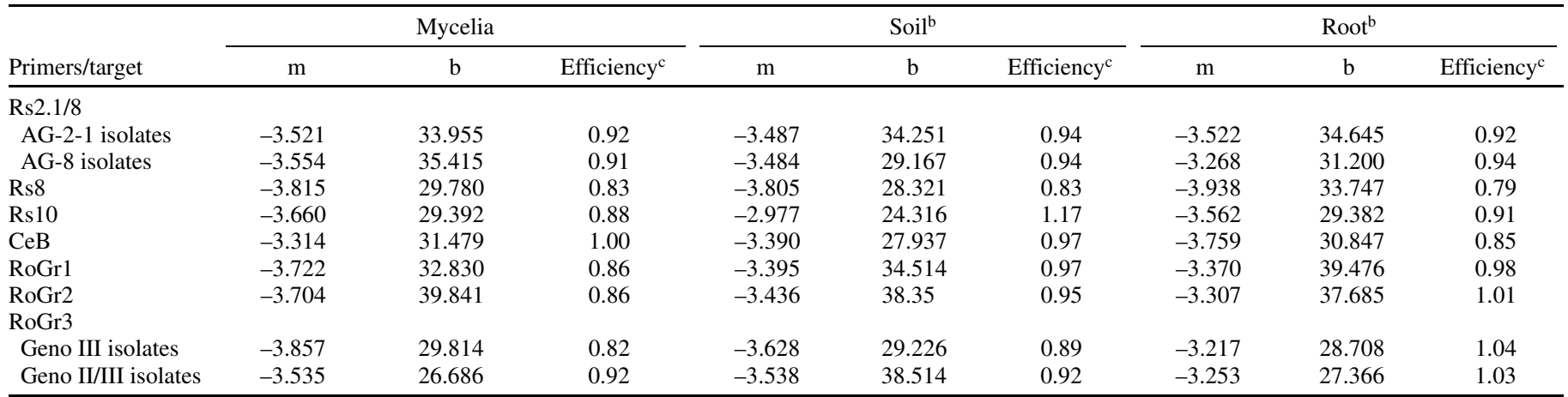

${ }^{\mathrm{a}} \mathrm{m}$, slope and $\mathrm{b}, y$ intercept from plots of cycle threshold $(\mathrm{Ct})\left(y\right.$ axis) versus $\log$ DNA in fg $\left(x\right.$ axis), where $y=\mathrm{m} x+\mathrm{b}$. Correlation coefficients $\left(r^{2}\right)$ were $>0.99$ for all plots. Samples were quantified in duplicate or triplicate.

${ }^{\mathrm{b}}$ Soil and root extracts were treated with PVP and Amberlite XAD-4, respectively. Soil data are means of four soils from Lind, WA, Mount Vernon, WA, Quincy, WA, and Fargo, ND, except RoGrp3 (soils from Mount Vernon, WA, Quincy, WA, and Fargo, ND).

${ }^{c}$ Amplification efficiency $=10^{(1 /-m)}-1(12)$, where $\mathrm{m}$ is the slope of the DNA standard curve generated using the primer pair.

TABLE 4. Quantification limits of Rhizoctonia-purified mycelial DNA in real-time polymerase chain reaction (PCR) assays

\begin{tabular}{lccc}
\hline Assay & Purified DNA (fg) $^{\mathrm{a}}$ & ${\text { DNA mixture }(\mathrm{fg})^{\mathrm{b}}}$ & Nontarget molar excess $^{\mathrm{c}}$ \\
\hline R. solani AG-2-1 & 4 & 16 & $39,000-136,000$ \\
R. solani AG-8 & 3 & 2 & 27,600 \\
R. solani AG-10 & 2 & 17 & $515-2,840$ \\
Binucleate & 7 & 8 & $190-3,770$ \\
R. oryzae I & 12 & 30 & $1,500-50,000$ \\
R. oryzae II & 21 & $<48$ & $8,900-25,400$ \\
R. oryzae III & 24 & $<97$ & $24,000-261,000$ \\
\hline
\end{tabular}

a Minimum amount of Rhizoctonia target DNA from cultured mycelia (purified) that can be reliably quantified in a 10- $\mu$ l reaction, specifically at cycle threshold $(\mathrm{Ct})=32$.

${ }^{\mathrm{b}}$ Minimum amount of purified Rhizoctonia target DNA that can be reliably quantified in a DNA mixture (10- $\mu$ PCR reaction), specifically at $\mathrm{Ct}=32$.

${ }^{c}$ Molar excess of nontarget Rhizoctonia DNA that can be present and still give reliable quantification of target DNA, expressed as the molar ratio of nontarget to target DNA. 
noidea (anamorph: R. carotae); Athelia epiphylla; and Ceratorhiza oryzae-sativa.

Blastn (1) comparisons revealed matches between nearly all the primers and bacterial, fungal, insect, plant, or mammalian genomic sequences from GenBank. In all cases, the deduced hybrid was 15 to 18 contiguous nucleotides and involved only one primer of the pair. To test whether single-primer hybridization could result in linear amplification, we attempted to amplify DNA from $R$. solani isolates 120208 (AG-2-1), 070308 (AG-8), 120244 (AG3 ), and AG-D with single primers Rs2.1/8F or Rs2.1/8R. No measurable fluorescence was obtained for any of the templates after 50 cycles (data not shown). These findings suggest that linear amplification due to single-primer hybridization will not result in false positives in the Q-PCR assays.

Q-PCR of agricultural samples. Alternative protocols were compared to optimize the quality of pathogen DNA from soil and root samples. $\mathrm{Ct}$ values for soil and root extracts spiked with Rhizoctonia DNA were decreased (improved) by as much as two units using the UltraClean Soil DNA Kit (MO BIO Laboratories) compared to other extraction kits (data not shown). However, the UltraClean Soil DNA Kit produced root and soil extracts that contained some inhibitors; amplification efficiencies for mycelial DNA spiked into these extracts were reduced compared to mycelial DNA in water (data not shown). Our findings suggested that interfering fluorescent compounds or other PCR inhibitors were present in the root and soil extracts. Treatment with

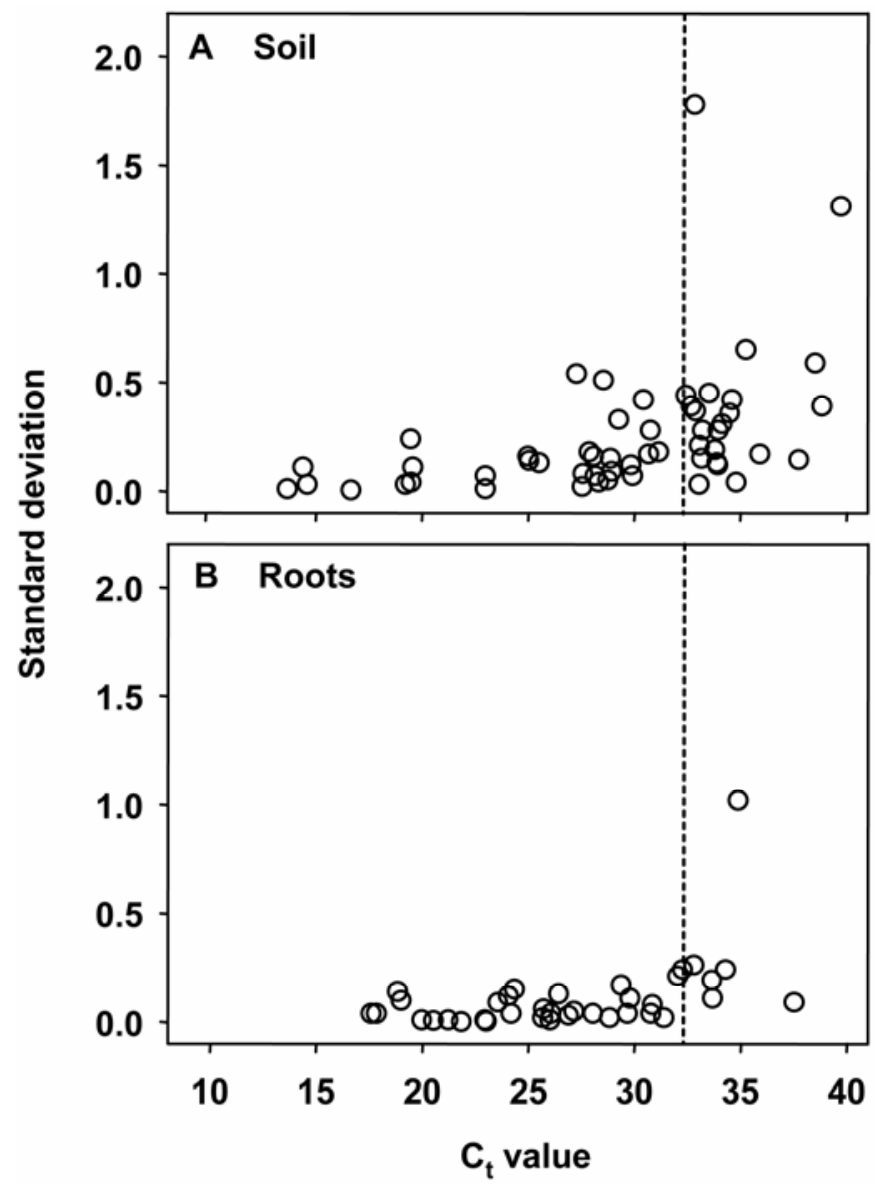

Fig. 2. Reproducibility of cycle threshold $(\mathrm{Ct})$ values in quantitative-polymerase chain reaction (Q-PCR) assays of pathogen DNA extracted from $\mathbf{A}$, soil samples or B, wheat roots. In each panel, mean $\mathrm{Ct}$ values are plotted against the standard deviations of the means ( 3 to 5 replicated PCR reactions per sample). Data represent 8 to 15 experiments using seven primer pairs. The $\mathrm{Ct}$ value of 32 (dotted line) is an empirically determined cut-off below which $\mathrm{Ct}$ values of replicated PCR are consistent and therefore deemed reliable for quantifying pathogen DNA. insoluble polyvinylpyrrolidone (PVP) (for soils) or Amberlite XAD-4 (for root tissue) incorporated into the extraction protocol improved efficiencies an average of 0.08 or 8 percentage points.

The AG-10 soil Q-PCR assay showed the most significant improvement with PVP compared with other assays (data not shown); maximum relative fluorescence was increased for each of the four soil types, and amplification efficiencies dropped from an average of 1.10 to 1.00 , where efficiencies of $>1.00$ indicated the presence of inhibitors. PVP treatment also improved reproducibility of the $\mathrm{Ct}$ values among replicated extracts, although it did not alter $\mathrm{Ct}$ values per se. As a result, $\mathrm{Ct}$ values of $\approx 22$ from soil DNA extracts that varied as much as 1.2 standard deviation units without PVP treatment amplified as reproducibly as purified fungal DNA at $\mathrm{Ct}$ values of up to 32 and standard deviation of $\leq 0.5$ (Fig. 2A). Pathogen DNA in wheat root extracts showed a similar trend following Amberlite XAD-4 treatment (Fig. 2B). The treatments rendered extracts from agricultural samples suitable for quantification in our assays.

Standard curve constants. To extrapolate DNA quantities from $\mathrm{Ct}$ values, standard curves were generated for each primer pair using five 10-fold dilutions of pathogen DNA from cultured mycelia and from soil and root extracts spiked with mycelial DNA; constants are listed in Table 3. As soil type was predicted to have an effect on amplification efficiency and hence pathogen quantification, we tested the performance of our Q-PCR primers for the four soils used in the previous section. Following PVP treatment, the extracts displayed lower $\mathrm{Ct}$ values and improved amplification efficiencies (data not shown). Soil type was not a significant factor in assay performance if extracts were treated with PVP.

Quantification versus detection. We noted that at $\mathrm{Ct}<33$, the variation among triplicate PCR reactions of a single sample was generally less than 0.5 standard deviation of the mean, whereas at $\mathrm{Ct} \geq 33$, the standard deviation of the mean $\mathrm{Ct}$ was 1.0 or greater (Fig. 2), and accurate quantification would require three or more reactions per sample. Therefore, the amount of target DNA that generated a $\mathrm{Ct}$ value between 32 and 33 was considered the quantification limit of the assays. This empirical limit ranged from 2 to $24 \mathrm{fg}$ in mycelial extracts and 2 to $97 \mathrm{fg}$ in soil extracts for $10 \mu \mathrm{l}$ of Q-PCR reaction (Table 4). At $\mathrm{Ct}>40$, target-independent fluorescence (nonspecific amplification) and amplicon $\mathrm{T}_{\mathrm{m}}$ shifts in excess of one degree frequently were observed. These results obscured amplicon analysis. However, an amplicon generated at $\mathrm{Ct}$ values between 33 and 40 sometimes melted as a single species at the expected $\mathrm{T}_{\mathrm{m}}$, indicating specific target amplification. In these cases, pathogen DNA was not quantifiable from duplicate Q-PCR reactions but could be unambiguously "detected." The detection limit of our assays was empirically determined at $\mathrm{Ct} \approx 40$, or approximately 10 to 120 attograms of DNA (depending upon the primer pair) in the Q-PCR reaction. The thresholds for quantification and detection of Rhizoctonia DNA in soil samples averaged 9 to $50 \mathrm{pg} / \mathrm{g}$ and $0.5 \mathrm{pg} / \mathrm{g}$ dry weight of soil, respectively.

Quantification of $R$. solani AG-8 in agricultural soils. Natural field soils from a direct-seeded farm near Ritzville, WA were analyzed for $R$. solani AG-8. Rhizoctonia root rot and bare patch have been diagnosed at this farm, which is part of a longterm cropping-system study (6). The relation between $\mathrm{Ct}$ and pathogen population density was determined by generating a soil standard curve consisting of three $R$. solani AG-8 isolates (Fig. 3), in which the amplification efficiency was 0.76. In general, triplicate extracts of a single soil sample yielded similar $\mathrm{Ct}$ values, and standard deviations averaged 0.24 . This standard curve was used to estimate populations of $R$. solani AG- 8 in the Ritzville soils. $R$. solani AG- 8 was detected in eight of nine soil samples collected at three field parcels displaying bare patches (Table 5). The amounts quantified in the soil samples were 0.4 to $19.0 \mathrm{ppg}$ or 9.4 to $780 \mathrm{pg} / \mathrm{g}$ soil. 


\section{DISCUSSION}

Using a matrix of 41 PNW Rhizoctonia isolates, we developed quantitative PCR assays for four AG of $R$. solani and three ITS genotypes of $R$. oryzae. To date, 97 of $98 \mathrm{PNW}$ isolates obtained from symptomatic soils or plants from throughout the PNW cereal production region sorted into one of these seven groups. Primers could be positioned to maximize sequence conservation within each group and sequence diversity among groups, because nucleotide polymorphisms within a group or genotype were infrequent. Polymorphisms among isolates of a single group were not extensive enough to alter amplicon melting profiles, and did not appear to complicate assay specificity and AG identification.

The Q-PCR assays were performed using an air-cooled capillary thermocycler that was suitable for amplicons of up to $450 \mathrm{bp}$. This allowed us to exploit both the ITS1 and ITS2 regions for primer design. However, either the forward or reverse primer and a second primer within the $5.8 \mathrm{~S}$ gene could be used to adapt the assays to Peltier (block)-based real-time PCR thermocyclers that require amplicons of $<200 \mathrm{bp}$. Target amplicons were verified on the basis of melting profiles rather than on size determination using gel electrophoresis. This type of quantification requires highly specific primers that amplify a single species.

PVP treatment was essential for reliable quantification of the $R$. oryzae genotypes in root and soil extracts. Improved amplification efficiencies in these extracts compared to mycelial extracts suggest that the latter might contain PCR inhibitors. PVP did not improve efficiency of the Rs8 and CeB primers. No unusual primerdimer or primer duplex formation was noted for these primer pairs. As expected, extensive stem-loop formation (GeneQuest, DNASTAR, Inc., Madison, WI) was observed for all amplicons, but it is possible that folds in the AG- 8 and binucleate amplicons especially impair priming or replication. We sometimes observed that cartridge-purified primers boosted amplification efficiencies, possibly due to enrichment of full-length oligonucleotides in cases of incomplete syntheses.

In our analysis of $28 \mathrm{PNW} R$. solani isolates, Q-PCR amplification predicted Blastn ITS sequence matches and vice versa, and supported previously observed correlations between ITS polymorphism and assay specificity at the level of AG. To further authenticate Blastn AG assignments, AG testing was attempted on 34 isolates using the clean slide method (18). In our hands, the AG-8 and AG-10 tester isolates (C1 and AG-10R) displayed hyphal fusion with isolates of other $\mathrm{AG}$, which confounded $\mathrm{AG}$

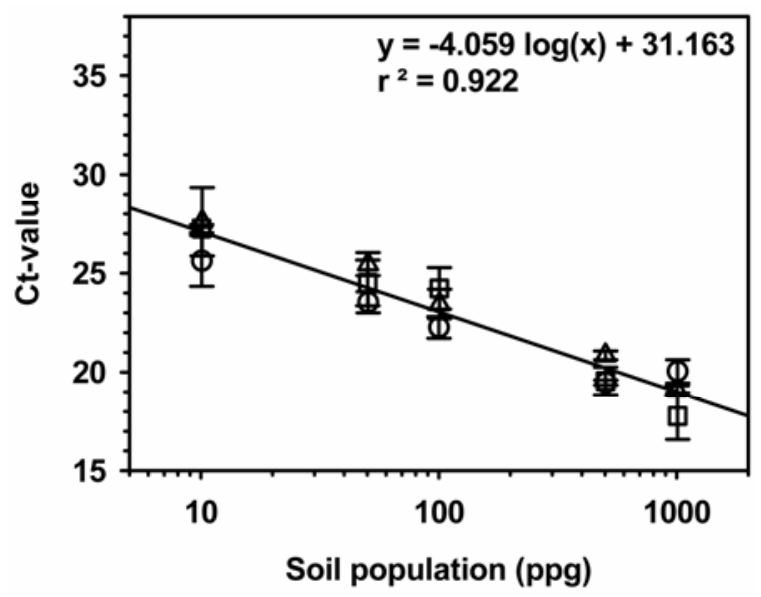

Fig. 3. Standard curve of Rhizoctonia solani anastomosis group (AG)-8 DNA extracted from soil. Pasteurized virgin Quincy soil was infested with isolates 050579 (circles), 070533 (triangles), or 120281 (squares) at 10, 50, 100, 500, and 1,000 propagules per gram (ppg) dry weight of soil. Bars indicate standard errors of the mean of three extractions per sample. Each extract was assayed in duplicate. identification. However, the AG testers served as useful reference isolates in cluster and primer annealing analyses.

In the absence of hyphal fusion data, we sought to identify AG using phylogenetic cluster analysis. This approach indicated that our 68 PNW $R$. solani isolates were comprised of four AG, including AG-2-1, AG-8, AG-10, and indicated monophyletic groupings with isolates from other countries. Sequence conservation on a global scale suggests that our primers will be useful beyond the PNW. Based only on 5.8S-ITS2 data, AG-8 and AG-10 were more related to each other than to AG-2-1. This finding supported relationships reported by Gonzalez et al. (13) for the entire ITS region. Phylogenetic analysis also indicated that our binucleate Rhizoctonia was different from AG-I; characterization of this group will require more extensive sequencing of a larger collection of isolates, and determination of their pathogenicity to various crops.

Three isolates were refractory to amplification in all $R$. solani Q-PCR assays. Blastn comparisons of the ITS sequences suggested that two isolates were $R$. oryzae. Subsequent analysis of the putative $R$. oryzae isolates using real-time PCR indicated that they were members of genotype III. Subtle differences in culture appearance, including morphological characters, complicated the previous identification of these isolates.

$R$. solani AG-8 is well-known in the PNW as the causal agent of Rhizoctonia root diseases of wheat and barley $(28,31)$. Our QPCR assays quantified populations of AG-8 in symptomatic soils from Ritzville, WA that were known to harbor Rhizoctonia in semiquantitative baiting studies (37). As the baiting method does not distinguish AG-8 from other AG, the two methods cannot be compared for soil samples. However, the rapidity and accuracy of Q-PCR will be more useful than the baiting method for assessing pathogen populations at Ritzville and other sites in the future.

Q-PCR-based analysis of our PNW Rhizoctonia collection suggests that $R$. solani AG-2-1, which is a pathogen of legumes and canola grown in rotation with the cereals (36), persists in the rhizosphere of cereals, and might account for the lack of effectiveness of canola as a break crop at some locales. The AG-I-like binucleate Rhizoctonia spp. is prevalent in apple orchard soils of the PNW (M. Mazzola, personal communication), in the strawberry rhizosphere (26), and in wheat growing regions $(10,31)$. However, it was not highly pathogenic to wheat and barley in greenhouse seedling assays (T. Paulitz, unpublished data), and its role in cereal root diseases or in cereal disease complexes remains to be established.

Although $R$. oryzae has been documented in the PNW, its population structure and diversity have not been extensively characterized at the molecular level. Seven of the $R$. oryzae

TABLE 5. Rhizoctonia solani anastomosis group (AG)-8 in agricultural soils from Ritzville, WA

\begin{tabular}{llcc}
\hline Sample & History $^{\mathrm{a}}$ & $\mathrm{ppg}^{\mathrm{bc}}$ & $\mathrm{pg} / \mathrm{g}^{\mathrm{bd}}$ \\
\hline 4-2a & MF-WW & $1.1 \pm 0.31$ & $33.7 \pm 10.6$ \\
4-3c & MF-WW & $19.2 \pm 5.7$ & $780.0 \pm 249$ \\
5-2b(a) & CF-WW & $4.0 \pm 1.9$ & $141.0 \pm 70$ \\
5-2d(c) & CF-WW & $1.4 \pm 0.7$ & $45.3 \pm 23.3$ \\
9-05 3d & SW-SW & $0.4 \pm 0.08$ & $9.4 \pm 2.5$ \\
T4 R2 & MF-WW & $1.9 \pm 0.9$ & $65.7 \pm 33.8$ \\
T4 R3a & MF-WW & $4.3 \pm 1.8$ & $152.0 \pm 68$ \\
T5 R3 & CF-WW & $2.2 \pm 0.6$ & $71.1 \pm 20.5$ \\
\hline
\end{tabular}

a MF-WW, mechanical fallow 2005 + winter wheat 2006; CF-WW, chemical fallow 2005 + winter wheat 2006; SW-SW, continuous spring wheat 2005 and 2006.

${ }^{\mathrm{b}}$ Determined from triplicate soil extracts and duplicate Q-PCR reactions per extract.

c Propagules per gram (ppg) of soil \pm standard error of the means; ppg values were determined using the soil standard curve shown in Figure 3.

${ }^{\mathrm{d}}$ Picograms of DNA per gram of soil \pm standard error of the means; pg/g values were determined using the soil standard curve parameters for $R$. solani AG- 8 shown in Table 4 . 
isolates known to be pathogenic to barley and wheat (39) were genotypes II/III or III, but analysis of more isolates is needed to determine whether this is a shared feature of all $R$. oryzae cereal pathogens. $R$. oryzae displays temperature- and location-dependent pathogenicity $(28,31)$; we are currently exploring the relationship between Q-PCR genotype, pathogenicity, and distribution of this species in the PNW. Putative R. oryzae isolate 120244 did not amplify in any of our assays; its ITS sequence had significant identity to that of an $R$. solani AG-3 from Japan (GenBank AB000024). AG-3 is a potato pathogen, but has been reported in PNW pathogen collections from wheat (31).

Occurrence of ITS genotypes II/III and III in many of the PNW $R$. oryzae suggests that the nuclei of these isolates either are heterokaryotic or harbor more than one ITS allele per genome. The ITS2 of $R$. oryzae genotype I appears to be distinct from II and III in cluster analyses, but all three genotypes are similar to W. circinata var. circinata from annual bluegrass (9) in Blastn comparisons of total ITS sequence, suggesting that the ITS regions of PNW R. oryzae are diverse and that polymorphisms are segregating among a single population of fungi. Sequence comparison data also indicate that our $R$. oryzae might better be classified as W. circinata var. circinata (21). However, evaluation of pathogenicity, host range, and relatedness based on other characteristics (41) will help to determine whether the three genotypes are $W$. circinata and whether they represent distinct pathovars.

Our Q-PCR assays can quantify $R$. solani AG-8 in natural soils at levels below population densities of 57 to $87 \mathrm{ppg}$ associated with patches in the field (37). However, a potential source of error in quantification is variation in the number of nuclei per cell, or in ITS copy number among isolates of the same species, as reported for Pythium (25). If such variations are on the order of two- to three-fold, they are not expected to significantly impact field population averages that will be obtained over a period of many years. Another source of variation is the field sampling scheme per se. Choice of sampling site within a parcel or bare patch is critical for diagnosis, as $R$. solani tends to be distributed in tight clusters or populations in the soil, whereas $R$. oryzae is more broadly distributed across the field (40). These considerations support the collection of multiple samples from parcels of interest.

Management of Rhizoctonia root diseases has proven to be a challenge $(4,6,8,38,46)$, in part because of the lack of distribution and population density profiles of specific pathogens in different regions of the PNW and under various tillage and rotation regimens. Although previous studies have addressed either single pathogenic species or pathogen complexes, a knowledge gap remains as to the most widespread pathogenic species/AG, their impact on yield reduction, and role of environmental factors such as rainfall and temperature on pathogen populations. Our Q-PCR assays will be useful in determining whether $R$. solani AG-8 and $R$. oryzae III occur in distinct versus overlapping locations and whether they coincide with pathogenic Pythium spp. The assays will also be useful for large-scale sampling of growers' parcels throughout the PNW over multiple years, an effort that will be needed for ultimately providing risk thresholds for planting to growers.

\section{ACKNOWLEDGMENTS}

We thank K. Adams, N. Walter, and A. Lutes for expert technical assistance; D. Mavrodi and T. Peever for valuable advice on cluster analyses; and F. Martin for discussions of AG-I and ITS copy number. Some nonRhizoctonia DNA was provided by L. Carris, X. Chen, T. Friesen, N. Grünwald, D. Johnson, M. Mazzola, T. Murray, R. Smiley, and D. Weller. This research was supported by a grant from the Washington Wheat Commission (Project No. 3061-4947) and by USDA-ARS Project No. 5248-22000-012-00D. References to a company and/or product by the USDA are only for the purposes of information and do not imply approval or recommendation of the product to the exclusion of others that may also be suitable.

\section{LITERATURE CITED}

1. Altschul, S. F., Madden, T. L., Schaffer, A. A., Zhang, J., Zhang, Z., Miller, W., and Lipman, D. J. 1997. Gapped BLAST and PSI-BLAST: A new generation of protein database search programs. Nucleic Acids Res. 25:3389-3402.

2. Bockus, W. W., and Shroyer, J. P. 1998. The impact of reduced tillage on soilborne plant pathogens. Annu. Rev. Phytopathol. 36:485-500.

3. Boysen, M., Borja, M., del Moral, C., Salazar, O., and Rubio, V. 1996. Identification at strain level of Rhizoctonia solani AG4 isolates by direct sequence of asymmetric PCR products of the ITS regions. Curr. Genet. 29:174-181.

4. Cook, R. J. 1990. Diseases caused by root-infecting pathogens in dryland agriculture. Adv. Soil Sci. 13:215-239.

5. Cook, R. J. 1992. Wheat root health management and environmental concern. Can. J. Plant Pathol. 14:76-85.

6. Cook, R. J., Schillinger, W. F., and Christensen, N. W. 2002. Rhizoctonia root rot and take-all of wheat in diverse direct-seed spring cropping systems. Can. J. Plant Pathol. 24:349-358.

7. Cubeta, M. A., Echandi, F., and Vilgalys, R. 1991. Characterization of anastomosis groups of binucleate Rhizoctonia species using restriction analysis of an amplified ribosomal RNA gene. Phytopathology 81:13951400.

8. Davis, R. 2005. Factors affecting occurrence and severity of Rhizoctonia root rot and Fusarium crown rot in direct-seeded cereals. M.S. thesis, Washington State University, Pullman, WA.

9. de la Cerda, K. A., Douhan, G. W., and Wong, F. P. 2007. Discovery and characterization of Waitea circinata var. circinata affecting annual bluegrass from the western United States. Plant Dis. 91:791-797.

10. Demirci, E. 1998. Rhizoctonia species and anastomosis groups isolated from barley and wheat in Erzurum, Turkey. Plant Pathol. 47:10-15.

11. Felsenstein, J. 1989. PHYLIP-Phylogeny Inference Package (Version 3.2). Cladistics 5:164-166

12. Ginzinger, D. G. 2002. Gene amplification using real-time quantitative PCR: An emerging technology hits the mainstream. Exp. Hematol. 30:503-512.

13. Gonzalez, D., Carling, D. E., Kuninaga, S., Vilgalys, R., and Cubeta, M. A. 2001. Ribosomal DNA systematics of Ceratobasidium and Thanatephorus with Rhizoctonia anamorphs. Mycologia 93:1138-1150.

14. Grönberg, H., Paulin, L., and Sen, R. 2003. ITS probe development for specific detection of Rhizoctonia spp. and Suillus bovinus based on Southern blot and liquid hybridization-fragment length polymorphism. Mycol. Res. 107:428-438.

15. Guillemaut, C., Edel-Hermann, V., Camporota, P., Alabouvette, C., Richard-Molard, M., and Steinborg, C. 2003. Typing of anastomosis groups of Rhizoctonia solani by restriction analysis of ribosomal DNA. Can. J. Microbiol. 49:556-568.

16. Higgins, D., Thompson, J., Gibson, T., Thompson, J. D., Higgins, D. G., and Gibson, T. J. 1994. CLUSTAL W: Improving the sensitivity of progressive multiple sequence alignment through sequence weighting, position-specific gap penalties and weight matrix choice. Nucleic Acids Res. 22:4673-4680.

17. Johanson, A., Turner, H. C., McKay, G. J., and Brown, A. E. 1998. A PCR-based method to distinguish fungi of the rice sheath-blight complex, Rhizoctonia solani, $R$. oryzae and $R$. oryzae-sativae. FEMS Microbiol. Lett. 162:289-294.

18. Kronland, W. C., and Stanghellini, M. E. 1988. Clean slide technique for the observation of anastomosis and nuclear condition of Rhizoctonia solani. Phytopathology 78:820-822.

19. Kuninaga, S., Natsuaki, T., Takeuchi, T., and Yokosawa, R. 1997. Sequence variation of the rDNA ITS regions within and between anastomosis groups in Rhizoctonia solani. Curr. Genet. 32:237-243.

20. Lees, A. K., Cullen, D. W., Sullivan, L., and Nicolson, M. J. 2002. Development of conventional and quantitative real-time PCR assays for the detection and identification of Rhizoctonia solani AG-3 in potato and soil. Plant Pathol. 51:293-302.

21. Leiner, R. H., and Carling, D. E. 1994. Characterization of Waitea circinata (Rhizoctonia) isolated from agricultural soils in Alaska. Plant Dis. 78:385-388.

22. Lievens, B., Brouwer, M., Vanachter, A. C. R. C., Cammue, B. P. A., and Thomma, B. P. H. J. 2006. Real-time PCR for detection and quantification of fungal and oomycete tomato pathogens in plant and soil samples. Plant Sci. 171:155-165.

23. Lübeck, M., and Poulsen, H. 2001. UP-PCR cross blot hybridization as a tool for identification of anastomosis groups in the Rhizoctonia solani complex. FEMS Microbiol. Lett. 201:83-89.

24. MacNish, G. C., Carling, D. E., Sweetingham, M. W., Ogoshi, A., and Brainard, K. A. 1995. Characterization of anastomosis group-10 (AG-10) of Rhizoctonia solani. Australas. Plant Pathol. 24:252-260.

25. Martin, F. N. 1990. Variation in ribosomal DNA repeat unit within single- 
oospore isolates of the genus Pythium. Genome 33:585-591.

26. Martin, F. N. 2000. Rhizoctonia spp. recovered from strawberry roots in central coastal California. Phytopathology 90:345-353.

27. Matsumoto, M. 2002. Trials of direct detection and identification of Rhizoctonia solani AG 1 and AG 2 subgroups using specifically primed PCR analysis. Mycoscience 43:185-189.

28. Mazzola, M., Wong, O. T., and Cook, R. J. 1996. Virulence of Rhizoctonia oryzae and $R$. solani AG-8 on wheat and detection of $R$. oryzae in plant tissues by PCR. Phytopathology 86:354-360.

29. McCartney, H. A., Foster, S. J., Fraaije, B. A., and Ward, E. 2003. Molecular diagnostics for fungal plant pathogens. Pest Manag. Sci. 59:129142 .

30. MacNish, G. C., and Neate, S. M. 1996. Rhizoctonia bare patch of cereals: An Australian perspective. Plant Dis. 80:965-971.

31. Ogoshi, A., Cook, R. J., and Bassett, E. N. 1990. Rhizoctonia species and anastomosis groups causing root rot of wheat and barley in the Pacific Northwest. Phytopathology 80:784-788.

32. Okubara, P. A., Schroeder, K. L., and Paulitz, T. C. 2005. Real-time PCR: Applications to studies on soilborne pathogens. Can. J. Plant Pathol. 37:300-313.

33. Page, R. D. M. 1996. TreeView: An application to display phylogenetic trees on personal computers. Comput. Appl. Biosci. 12:357-358.

34. Pascual, C. B., Toda, T., Raymondo, A. D., and Hyakumachi, M. 2000. Characterization by conventional techniques and PCR of Rhizoctonia solani isolates causing banded leaf sheath blight in maize. Plant Pathol. 49:108-118.

35. Paulitz, T. C., and Adams, K. 2003. Composition and distribution of Pythium communities in wheat fields in eastern Washington state. Phytopathology 93:867-873.

36. Paulitz, T. C., Okubara, P. A., and Schillinger, W. F. 2006. First report of damping-off of canola caused by Rhizoctonia solani AG 2-1 in Washington State. Plant Dis. 90:829.

37. Paulitz, T. C., and Schroeder, K. L. 2005. A new method for the quantification of Rhizoctonia solani and $R$. oryzae from soil. Plant Dis. 89:767772.

38. Paulitz, T. C., Smiley, R. W., and Cook, R. J. 2002. Insights into the prevalence and management of soilborne cereal pathogens under direct seeding in the Pacific Northwest, U.S.A. Can. J. Plant Pathol. 24:416-428.

39. Paulitz, T. C., Smith, J. D., and Kidwell, K. K. 2003. Virulence of Rhizoctonia oryzae on wheat and barley cultivars from the Pacific Northwest. Plant Dis. 87:51-55.

40. Paulitz, T. C., Zhang, H., and Cook, R. J. 2003. Spatial distribution of
Rhizoctonia oryzae and rhizoctonia root rot in direct-seeded cereals. Can. J. Plant Pathol. 25:295-303.

41. Priyatmojo, A., Yamauchi, R., Carling, D. E., Kageyama, K., and Hyakumachi, M. 2002. Differential of three varieties of Rhizoctonia circinata; var. circinata, var. oryzae and var. zeae on the basis of cellular fatty acid composition. J. Phytopathol. 150:1-5.

42. Pumphrey, F. V., Wilkins, D. E., Hane, D. C., and Smiley, R. W. 1987. Influence of tillage and nitrogen fertilizer on Rhizoctonia root rot (bare patch) of winter wheat. Plant Dis. 71:125-127.

43. Raaijmakers, J. M., Weller, D. M., and Thomashow, L. S. 1997. Frequency of antibiotic-producing Pseudomonas spp. in natural environments. Appl. Environ. Microbiol. 63:881-887.

44. Salazar, O., Julian, M. C., and Rubio, V. 2000. Primers based on specific rDNA-ITS sequences for PCR detection and Rhizoctonia solani, $R$. solani AG 2 subgroups and ecological types, and binucleate Rhizoctonia. Mycol. Res. 104:281-285.

45. Schena, L., Nigro, F., Ippolito, A., and Gallitelli, D. 2004. Real-time quantitative PCR: A new technology to detect and study phytopathogenic and antagonistic fungi. Eur. J. Plant Pathol. 110:893-908.

46. Schillinger, W. F., and Paulitz, T. C. 2006. Reduction of Rhizoctonia bare patch in wheat with barley rotations. Plant Dis. 90:302-306.

47. Schroeder, K. L., Okubara, P. A., Tambong, J. T., Levesque, C. A., and Paulitz, T. C. 2006. Identification and quantification of pathogenic Pythium spp. from soils in eastern Washington using real-time PCR. Phytopathology 96:637-647.

48. Smith, J. D., Kidwell, K. K., Evans, M. A., Cook, R. J., and Smiley, R. W. 2003. Evaluation of spring cereal grains and wild Triticum germplasm for resistance to Rhizoctonia solani AG-8. Crop Sci. 43:701-709.

49. Toda, T., Mushika, T., Hayakawa, T., Tanaka, A., Tani, T., and Hyakumachi, M. 2005. Brown ring match: A new disease on bentgrass caused by Waitea circinata var. circinata. Plant Dis. 89:536-542.

50. Ward, E., Foster, S. J., Fraaije, B. A., and McCartney, H. A. 2004. Plant pathogen diagnostics: Immunological and nucleic acid-based approaches. Ann. Appl. Biol. 145:1-16.

51. Weller, D. M., Cook, R. J., MacNish, G., Bassett, E. N., Powelson, R. L., and Petersen, R. R. 1986. Rhizoctonia root rot of small grains favored by reduced tillage in the Pacific Northwest. Plant Dis. 70:70-73.

52. White, T. J., Bruns, T., Lee, S., and Taylor, J. 1990. Amplification and direct sequencing of fungal ribosomal RNA genes for phylogenetics. Pages 315-322 in: PCR Protocols, A Guide to Methods and Applications. M. A. Innis, D. H. Gelfand, J. J. Sninsky, and T. J. White, eds. Academic Press, San Diego, CA. 